\title{
PREGNANCY AND TRACE ELEMENTS: THE PROTECTIVE EFFECT OF COMPOUNDS OF AN ESSENTIAL TRACE ELEMENT-SELENIUM-AGAINST THE PECULIAR TOXIC EFFECTS OF CADMIUM DURING PREGNANCY
}

\author{
J. PAR̆IZZEK, I. OŠT̆ÁDALOVÁ, I. BENES̆ AND A. BABICKÝ
}

Institute of Physiology, Laboratory of Physiology and Pathophysiology of Reproduction, Czechoslovak Academy of Sciences and Radioisotope Laboratories of the Institutes for Biological Research, Czechoslovak Academy of Sciences, Prague-Krč, Czechoslovakia

\section{(Received 5th March 1968)}

One single injection of cadmium salts, in a dose sufficient to produce complete testicular necrosis (Pařizek \& Záhoř, 1956; Pařizek, 1957, 1960) results, when administered to pregnant rats, in a complete destruction of the foetal part of the placentae and death of the foetuses (Paŕizek, 1964). The placental damage is specific for cadmium and a constant phenomenon already at earlier stages of pregnancy; however, in addition to this, during the last 4 days of pregnancy of rats the pathologic changes in the placentae and foetuses are accompanied by additional pathologic changes affecting the maternal organism: during the last 4 days of pregnancy the administration of cadmium salts-in a dose well tolerated by non-gravid or post-partum rats-is highly lethal not only for foetuses but for a very high proportion of pregnant rats, producing here pathologic changes specific for this period of pregnancy and quite unusual for cadmium intoxication in non-gravid rats (Pařizek, 1965). Simultaneous administration of selenite is highly efficient in preventing the testicular necrosis after injection of cadmium salt (Kar, Das \& Mukerji, 1960; Mason, Young \& Brown, 1964; Mason \& Young, 1967; Gunn \& Gould, 1967; Gunn, Gould \& Anderson, 1968). It was of interest, therefore, to learn how far the peculiar toxic effects of cadmium during pregnancy could be prevented by selenite administration in a similar way.

Pregnant rats (Wistar Substrain Konárovice) were injected subcutaneously with cadmium acetate $(0.03 \mathrm{~m}$-mole $/ \mathrm{kg}$ body weight $)$ on the 21 st day of pregnancy. One group of rats (ten animals) served as controls treated with cadmium acetate only or with cadmium acetate and sodium sulphite $(0 \cdot 04$ $\mathrm{m}$-mole $/ \mathrm{kg}$ b.w.; five animals). Another group (twenty animals) received, simultaneously with cadmium acetate, an injection of sodium selenite $(0.04$ $\mathrm{m}$-mole $/ \mathrm{kg} \mathrm{b.w.).} \mathrm{All} \mathrm{substances} \mathrm{used} \mathrm{were} \mathrm{injected} \mathrm{as} 0.02 \mathrm{~m}$ solutions subcutaneously at different sites of the body. Body weight on the 1st day of pregnancy (day of the appearance of spermatozoa in the vaginal smear) was used for the determination of the dose of substances injected. In all contol rats, treated 
with cadmium acetate only or with cadmium acetate and sodium sulphite, typical macroscopic and histologic changes in the placentae (Paŕizek, 1964) were observed, connected in all cases with the death of foetuses. In $80 \%$ of these rats typical severe pathologic changes affecting the kidneys of pregnant rats were observed (bilateral haemorrhagic renal necrosis), $40 \%$ of pregnant rats in these control groups died within the first $24 \mathrm{hr}$ of cadmium intoxication. The pathologic changes observed in these rats and their incidence were in very good agreement with the results reported previously with a large group of 140 pregnant rats (Pařízek, 1965). However, in contrast with this, no typical changes were observed in the placentae when cadmium salts were injected simultaneously with sodium selenite. Foetuses survived in all these rats and no maternal death occurred. Haemorrhagic renal necrosis, typical for cadmium intoxication during the last 4 days of pregnancy, was not observed in rats treated simultaneously with cadmium acetate and sodium selenite. Thus, in agreement with previous preliminary reports (Pařizek, 1967), selenite proved to be highly effective in preventing the peculiar toxic effect of cadmium during pregnancy; preliminary experiments suggest that $\mathrm{D}, \mathrm{L}$-selenomethionine has an analogous protective effect. The presence of the placentae in the pregnant organism and the damage produced in this organ seem to have a decisive role for the development of specific symptoms produced by cadmium intoxication during the last period of pregnancy (Pařízek, 1967). It was of importance, therefore, to exclude the possibility that selenite administration could decrease the amount of cadmium reaching this critical organ. In further experiments another group of ten rats (on the 21st day of pregnancy) was injected with cadmium salt labelled with ${ }^{115 \mathrm{~m}} \mathrm{Cd}$ or ${ }^{109} \mathrm{Cd}$. Half of these rats received sodium selenite simultaneously. The dose of cadmium acetate and sodium selenite was the same as in the previous experiment. Pairs of rats from both groups were killed successively at different time intervals within 6 to $10 \mathrm{hr}$ after the cadmium injection and the radio-activity in the placentae was determined: the amount of cadmium detected in the placentae of rats treated with selenite was not decreased but, in all cases, markedly higher than the amount of cadmium in rats treated with cadmium acetate only.

The protective effect of selenite against the peculiar toxicity of cadmium in the pregnant organism could be of interest from the aspect of selenium as an essential nutrient (Schwarz, 1961; Rosenfeld \& Beath, 1964; Muth, 1967) and from the aspect of surprisingly high amounts of cadmium present in the human body (cf. Schroeder, 1967). It seemed to be of importance to decide, first of all, if the protective effect of selenium compounds is specific for the toxic effects of cadmium related to reproduction only (cf. Pařizek, 1967) or if selenium compounds affect the toxicity of cadmium in other systems in a similar way. Further experiments revealed that even non-pregnant rats, treated with extremely high doses of cadmium salts, highly lethal in control rats, survive well when injected simultaneously with inorganic (selenite) or organic (D,L-selenomethionine) compounds of selenium. The blood level of cadmium of these rats protected by selenium compounds is not decreased but surprisingly very markedly increased. Fractionation of blood plasma of these rats by means of Sephadex has shown that a highly increased amount of cadmium is present, 
firmly bound in the macromolecular fractions of blood plasma (Pařizek, Beneš, Kalousková, Oštádalová, Lener, Babický \& Beneš, 1968). This seems to indicate a change in the binding of cadmium in the organism which could well explain the change in its toxicity; this effect of selenium compounds seems to be more general in character and not related only to the selective effect of cadmium in certain reproductive organs (Pařízek, Oštádalová, Beneš, Babický \& Beneš 1967). In this connection it seems to be of importance that selenite protects the organism against the toxic effects of bivalent mercury in a similar way (Parrízek \& Ošádalová, 1967).

\section{REFERENCES}

Guns, S. A. \& Gound, T. C. (1967) Specifity of response in relation to cadmium, zinc and selenium. In: Selenium in Biomedicine. Ed. O. H. Muth. The Avi Publishing Company, Westport, Conn.

Gunn, S. A., Gould, T. G. \& ANDerson, W. A. D. (1968) Mechanisms of zinc, cysteine and selenium protection against cadmium-induced vascular injury to mouse testis. 7. Reprod. Fert. 15, 65.

Kar, A. B., Das, R. P. \& MukerjI, F. N. I. (1960) Prevention of cadmium induced changes in the gonads of rat by zinc and selenium-a study in antagonism between metals in the biological system. Proc. natn. Inst. Sci. India, B, 26, Suppl., 40.

Mason, K. E. \& Young, J. O. (1967) Effectiveness of selenium and zinc in protecting against cadmium-induced injury of the rat testis. In: Selenium in Biomedicine. Ed. O. H. Muth. The Avi Publishing Company Westport, Conn.

Mason, K. E., Young, J. O. \& Brown, J. A. (1964) Effectiveness of selenium and zinc in protecting against cadmium-induced injury of the rat testis. Anat. Rec. 148, 309.

Muth, O. H. (1967) Selenium in biomedicine. The Avi Publishing Company, Westport, Conn.

Paḱízek, J. (1957) The destructive effect of cadmium ion on testicular tissue and its prevention by zinc. 7. Endocr. 15, 56.

Paǩizizk, J. (1960) Sterilization of the male by cadmium salts. F. Reprod. Fert. 1, 294.

PAŔfzek, J. (1964) Vascular changes at sites of oestrogen biosynthesis produced by parenteral injection of cadmium salts: the destruction of placenta by cadmium salts. f. Reprod. Fert. 7, 263.

PAŘízek, J. (1965) The peculiar toxicity of cadmium during pregnancy-an experimental 'toxaemia of pregnancy' induced by cadmium salts. 7. Reprod. Fert. 9, 111.

Paǩízek, J. (1967) Trace elements and reproduction. In: Preventive Medicine and Family Planning. I.P.P.F., London.

Paǩízex, J., Beneš, I., Kalousková, J., Ošťádalová, I., Lener, J., Babický, A. \& Beneš, J. (1968) Metabolicke vztahy mezi nékterými stopovými prvky v organismu: kadmium, zinek, selen a rtut. (Metabolic interrelations of certain trace elements in the organism: cadmium, zinc, selenium and mercury.) Čslká Fysiol. (In press).

Pař́zze, J. \& OŠŕádalová, I. (1967) The protective effect of small amounts of selenite in sublimate intoxication. Experientia, 23, 142.

Paǩízek, J., Ošǐ́́daloová, I., Beně̌, I., BabickÝ, A. \& Beneł̌, J. (1967) Ochranný úćinek stopových množství seleničitanu při otravě sloučeninami kadmia a dvojmocné rtuti. (The protective effect of trace amounts of selenite in the intoxication with compounds of cadmium and bivalent mercury). Csiká Fysiol. 16, 41.

Paर̌ízex, J. \& ZÁHǒ̌, Z. (1956) Effect of cadmium salts on testicular tissue. Nature, Lond. 177, 1036.

Rosenfeld, I. \& BeAth, O. A. (1964) Selenium, geobotany, biochemistry, toxicity and nutrition. Academic Press, New York and London.

Schroeder, H. D. (1967) Cadmium, chromium and cardiovascular disease. Circulation, 35, 570.

Schwarz, K. (1961) The nutritional significance of selenium. Fedn Proc. Fedn Am. Socs exp. Biol. 20, 665 . 